\title{
Dietary Cation-Anion Difference Effects on Performance and Acid-Base Status of Dairy Cows Postpartum ${ }^{1}$
}

\author{
W. $\mathrm{Hu}^{\star 2,3}$ M. R. Murphy, ${ }^{*}$ P. D. Constable, $\dagger^{4}$ and E. Block \\ *Department of Animal Sciences, University of Illinois, Urbana 61801 \\ †Department of Veterinary Clinical Medicine, University of Illinois, Urbana 61802 \\ $\ddagger$ Arm \& Hammer Animal Nutrition Group, Church \& Dwight Co. Inc., Princeton, NJ 08543
}

\section{ABSTRACT}

Our objective was to examine the effect of dietary cation-anion difference (DCAD) on performance and acid-base status of cows postpartum. Sixteen Holstein and 8 Jersey multiparous cows were used immediately after calving to compare $2 \mathrm{DCAD}$ [22 or 47 milliequivalents $(\mathrm{Na}+\mathrm{K}-\mathrm{Cl}-\mathrm{S}) / 100 \mathrm{~g}$ of dry matter (DM)] in a completely randomized design. The corn silagebased diets were formulated to contain $19.0 \%$ crude protein, $25.4 \%$ neutral detergent fiber, $15.0 \%$ acid detergent fiber, and $1.69 \mathrm{Mcal}$ of net energy for lactation per kilogram (on a DM basis). An additional $2.3 \mathrm{~kg}$ of alfalfa hay was fed during the first $5 \mathrm{~d}$ postpartum, and then milk, blood, and urine samples were collected weekly for 6 wk. Repeated-measures (with an extra between-cow effect) mixed model analysis indicated that DCAD did not affect DM intake (18.2 and 18.3 $\mathrm{kg} / \mathrm{d}$ ), milk production ( 33.5 and $33.3 \mathrm{~kg} / \mathrm{d}$ ), milk composition (3.96 and $4.11 \%$ fat, 3.11 and $3.00 \%$ protein, and 8.95 and $8.83 \%$ solids-not-fat), jugular venous blood $\mathrm{pH}$ (7.395 and 7.400), $\mathrm{HCO}_{3}{ }^{-}$concentration (27.3 and $27.6 \mathrm{mEq} / \mathrm{L})$, or partial pressure of $\mathrm{CO}_{2}(46.7$ and $46.5 \mathrm{mmHg})$. Elevated coccygeal venous plasma branched-chain AA (431 and $558 \mu M$ ) and ratio of essential AA to total AA (0.390 and 0.434) in cows with DCAD of $22 \mathrm{vs} .47 \mathrm{mEq} / 100 \mathrm{~g}$ of $\mathrm{DM}$ indicated that $\mathrm{N}$ metabolism in the rumen was affected, probably resulting in more microbial protein flowing to the small intestine. Urinary $\mathrm{pH}$ tended to increase with DCAD (8.12 vs. 8.20). Higher net acid excretion in cows with DCAD of 22 vs. $47 \mathrm{mEq} / 100 \mathrm{~g}$ of DM (-24

\footnotetext{
Received August 7, 2006.

Accepted March 20, 2007.

${ }^{1}$ Supported by Illinois Experiment Station NE-132 "Environmental and Economic Impacts of Nutrient Management on Dairy Forage Systems" and Church \& Dwight Co. Inc., Arm \& Hammer Animal Nutrition Group, Princeton, NJ.

${ }^{2}$ Corresponding author: whu@udel.edu

${ }^{3}$ Current address: Department of Animal and Food Sciences, University of Delaware, Newark, DE 19716.

${ }^{4}$ Current address: Department of Veterinary Clinical Sciences, Purdue University, 625 Harrison Street, West Lafayette, IN 47907.
}

and $-41 \mathrm{~m} M: \mathrm{m} M)$ suggested that net acid excretion was much more indicative of acid load than blood acidbase parameters in cows postpartum. Intake of DM and performance of cows postpartum were not improved when DCAD increased from 22 to $47 \mathrm{mEq} / 100$ $\mathrm{g}$ of DM, likely because cows immediately after calving respond more variably to dietary treatments and that makes treatment effects difficult to detect.

Key words: dietary cation-anion difference, performance, acid-base status, dairy cow

\section{INTRODUCTION}

Tucker et al. (1988) were the first to evaluate DCAD in lactating dairy cows and reported that milk yield was $9 \%$ higher when a diet with DCAD of 20 vs. -10 $\mathrm{mEq}(\mathrm{Na}+\mathrm{K}-\mathrm{Cl}) / 100 \mathrm{~g}$ of DM was fed. Significant influences of DCAD on lactating cows were also found in subsequent studies (West et al., 1991, 1992; Delaquis and Block, 1995a,b). A recent meta-analysis of previous research (Hu and Murphy, 2004) indicated that DCAD altered acid-base status and affected performance of lactating dairy cows.

In transition from pregnancy to lactation, dairy cows require dramatic increases in nutrient intake to support milk production. An increased proportion of concentrate in the ration is a routine practice to help highproducing dairy cows meet their net energy requirements. Excess ingestion of feeds rich in readily available carbohydrates may result in a substantial acid load. Manipulating DCAD might benefit lactating dairy cows immediately after calving to about $50 \mathrm{~d}$ postpartum. However, there was only a little information available about DCAD effects on those lactating cows. Chan et al. (2005) reported that increasing DCAD from 20 to $50 \mathrm{mEq} / 100 \mathrm{~g}$ of DM had no effects on DMI and milk production in cows from 0 to $42 \mathrm{~d}$ postpartum. Further efforts need to be made to examine the effect of DCAD on milk performance, acid-base status, and $\mathrm{N}$ and mineral metabolism in cows postpartum. 
Table 1. Ingredients and nutrient composition in experimental diets (DM basis) in 2 breeds fed diets with 2 levels of DCAD

\begin{tabular}{|c|c|c|}
\hline & \multicolumn{2}{|c|}{$\mathrm{DCAD}^{1}$} \\
\hline & 22 & 47 \\
\hline \multicolumn{3}{|l|}{ Ingredient (\%) } \\
\hline Corn silage $^{2}$ & 50.0 & 50.0 \\
\hline Corn grain, cracked & 18.5 & 17.0 \\
\hline Soybean meal, $48 \%$ & 27.7 & 28.1 \\
\hline $\mathrm{NaCl}$ & 0.34 & 0.34 \\
\hline Dicalcium phosphate & 0.99 & 0.64 \\
\hline $\mathrm{MgO}$ & 0.09 & 0.09 \\
\hline Limestone & 1.52 & 1.06 \\
\hline $\mathrm{NaHCO}_{3}$ & 0.42 & 1.35 \\
\hline $\mathrm{K}_{2} \mathrm{CO}_{3}$ & 0.23 & 1.21 \\
\hline Mineral and vitamin premix ${ }^{3}$ & 0.19 & 0.19 \\
\hline \multicolumn{3}{|l|}{ Composition } \\
\hline $\mathrm{CP}, \%$ & 19.4 & 19.9 \\
\hline $\mathrm{NE}_{\mathrm{L}}, \mathrm{Mcal} / \mathrm{kg}$ & 1.69 & 1.64 \\
\hline $\mathrm{ADF}, \%$ & 14.7 & 15.2 \\
\hline $\mathrm{NDF}, \%$ & 26.3 & 27.1 \\
\hline $\mathrm{NFC}^{4}, \%$ & 49.5 & 46.3 \\
\hline $\mathrm{Ca}, \%$ & 1.23 & 1.00 \\
\hline $\mathrm{P}, \%$ & 0.59 & 0.56 \\
\hline $\mathrm{Mg}, \%$ & 0.28 & 0.28 \\
\hline $\mathrm{K}, \%$ & 1.28 & 1.85 \\
\hline $\mathrm{Na}, \%$ & 0.29 & 0.63 \\
\hline $\mathrm{Cl}, \%$ & 0.41 & 0.39 \\
\hline $\mathrm{S}, \%$ & 0.20 & 0.20 \\
\hline $\mathrm{DCAD}, \mathrm{mEq} / 100 \mathrm{~g}$ of $\mathrm{DM}$ & 21.8 & 51.1 \\
\hline
\end{tabular}

${ }^{1} \mathrm{DCAD}$ in milliequivalents of $(\mathrm{Na}+\mathrm{K}-\mathrm{Cl}-\mathrm{S}) / 100 \mathrm{~g}$ of $\mathrm{DM}$.

${ }^{2}$ Contained $37.1 \% \mathrm{DM}, 44.0 \% \mathrm{NDF}, 25.0 \% \mathrm{ADF}$, and $6.0 \% \mathrm{CP}$ on a DM basis.

${ }^{3}$ Contained $5.00 \% \mathrm{Mg}, 10.00 \% \mathrm{~S}, 7.50 \% \mathrm{~K}, 2.00 \% \mathrm{Fe}, 3.00 \% \mathrm{Zn}$, $3.00 \% \mathrm{Mn}, 5,000.0 \mathrm{mg} / \mathrm{kg} \mathrm{Cu}, 250.0 \mathrm{mg} / \mathrm{kg} \mathrm{I}, 40.0 \mathrm{mg} / \mathrm{kg} \mathrm{Co}, 150.0$ $\mathrm{mg} / \mathrm{kg}$ Se, 2,205,000 IU/kg vitamin A, 661,500 IU/kg vitamin $\mathrm{D}_{3}$, and $22,050 \mathrm{IU} / \mathrm{kg}$ vitamin $\mathrm{E}$.

${ }^{4} \mathrm{NFC}=100-\mathrm{CP}-$ fat $-\mathrm{NDF}-$ ash

\section{MATERIALS AND METHODS}

\section{Experimental Design and Animal Care}

Twenty-four multiparous cows (16 Holsteins and 8 Jerseys) were divided into 2 groups (12 cows per group). Because not all cows could be obtained at once, cows entered the experiment as pairs based on breed, parity, and previous milk yield; members of each pair were assigned randomly to DCAD of either 22 or 47 $\mathrm{mEq}(\mathrm{Na}+\mathrm{K}-\mathrm{Cl}-\mathrm{S}) / 100 \mathrm{~g}$ of $\mathrm{DM}$ diets.

The diets were composed of $50 \%$ concentrate mix of mainly cracked corn-soybean meal and 50\% conventional corn silage on a DM basis. The DCAD was varied by using $\mathrm{NaHCO}_{3}$ and $\mathrm{K}_{2} \mathrm{CO}_{3}$ in the concentrate mix (Table 1).

Cows were housed in tie stalls indoors except during milking and during the exercise period on a dirt lot between the a.m. milking and feeding. Feed offered was adjusted daily and $110 \%$ of consumption the previous day (as-fed basis) was provided at 1100 and $1630 \mathrm{~h}$.
All cows were offered experimental diets immediately after calving to $47 \mathrm{DIM}$; an additional $2.3 \mathrm{~kg} / \mathrm{d}$ of alfalfa hay was fed during the first $5 \mathrm{~d}$ postpartum. Water was available for ad libitum consumption. Cows were milked twice daily at approximately 0600 and $1500 \mathrm{~h}$.

\section{Sample Collection and Analysis}

Drinking Water.Drinking water was collected in 1,000-mL containers weekly, the water samples were stored at $-15^{\circ} \mathrm{C}$ until the end of the experiment, and then composited and pooled for mineral analysis (Dairy One Forage Laboratory, Ithaca, NY). Drinking water analysis indicated (per $\mathrm{kg}$ ) $41.8 \mathrm{mg}$ of $\mathrm{Na},<0.1$ $\mathrm{mg}$ of K, $12.0 \mathrm{mg}$ of Cl, $0.0 \mathrm{mg}$ of S, $17.1 \mathrm{mg}$ of Ca, 0.1 $\mathrm{mg}$ of $\mathrm{P}$, and $13.3 \mathrm{mg}$ of $\mathrm{Mg}$, which suggested that the mineral intake from drinking water had little effect on total mineral intake.

Feeds and Orts. Feed intake of each cow was recorded during the experimental period from 6 to 47 DIM; samples of feed and orts were collected weekly. Orts were measured daily before the a.m. feeding and scored visually for DM content. Ort scores (integers from 1 to 4 ) were related to their actual DM content by drying all orts samples in a forced-air oven at $55^{\circ} \mathrm{C}$ weekly (Shah et al., 2004). Weekly samples of corn silage, concentrate mix, and the TMR were stored at $-15^{\circ} \mathrm{C}$ until the end of the experiment, and then composited and pooled for later analysis. Nutrient contents of corn silage, concentrate, and the TMR were analyzed by wet chemistry for DM, CP, ADF, NDF (Dairy One Forage Laboratory). Also, energy concentration was calculated (Dairy One Forage Laboratory). The nutrient composition presented in Table 1 was based on calculation from nutrient content analysis of corn silage and concentrate.

Urine. Urine was sampled weekly from 6 to 47 DIM. Cows were manually stimulated to urinate at $0900 \mathrm{~h}$, and a sample of midstream urine was collected in 50$\mathrm{mL}$ plastic containers. Urine $\mathrm{pH}$ was measured immediately, and $30 \mathrm{~mL}$ of urine was stored at $-15^{\circ} \mathrm{C}$ for further analysis. Urine concentrations of $\mathrm{Na}^{+}, \mathrm{K}^{+}$, and $\mathrm{Cl}^{-}$were determined using an ion-selective electrode; urine $\mathrm{Ca}$, urea $\mathrm{N}$, and creatinine were measured spectrophotometrically. All these assays were performed on the Hitachi 917 analyzer (Roche, Indianapolis, IN) using Roche diagnostic reagents.

Urine titratable acidity (TA) and ammonium concentrations were determined by titration of urine samples with $0.1 \mathrm{~N} \mathrm{NaOH}$, which was standardized by potassium biphthalate (Chan, 1972). Net acid excretion (NAE) was the sum of urine TA measured and ammonium; the urine TA measured was actually the 
amount of urinary TA minus $\mathrm{HCO}_{3}^{-}$(Chan, 1972). Urinary mineral excretions $\left(\mathrm{Na}^{+}, \mathrm{K}^{+}, \mathrm{Cl}^{-}\right.$, and $\left.\mathrm{Ca}\right)$ were expressed as minerals to creatinine concentration to overcome variations in urine volume among animals.

Blood. Blood was sampled weekly from 6 to 47 DIM. Immediately before the a.m. feeding, $5 \mathrm{~mL}$ of jugular venous blood was collected anaerobically with a plastic syringe containing lithium heparin, capped, placed on crushed ice, and analyzed for $\mathrm{pH}$, partial pressure of $\mathrm{CO}_{2}\left(\mathbf{p} \mathbf{C O}_{2}\right)$, partial pressure of $\mathrm{O}_{2}\left(\mathbf{p} \mathbf{O}_{2}\right), \mathrm{HCO}_{3}{ }^{-}$, and base excess in a blood gas analyzer (Rapidlab 850 System, Bayer Diagnostics, Tarrytown, NY) within $2 \mathrm{~h}$. Simultaneously, $\mathrm{Na}^{+}, \mathrm{K}^{+}, \mathrm{Cl}^{-}$, and $\mathrm{Ca}^{2+}$ were determined using ion-selective electrode, and anion gap was calculated in the blood gas analyzer (Rapidlab 850 system, Bayer Diagnostics). Values of $\mathrm{pH}, \mathrm{pCO}_{2}$, and $\mathrm{pO}_{2}$ were corrected for rectal temperature. Coccygeal venous blood (there was slight chance for artery blood to be included in the blood sample, but venous blood is referred to herein) was also collected in Vacutainers (Becton Dickinson, Franklin Lakes, NJ) containing lithium heparin, placed on crushed ice, and immediately centrifuged at $1,500 \times g$ for $15 \mathrm{~min}$. Plasma was then retrieved, transferred to 5 -mL plastic tubes, and frozen at $-15^{\circ} \mathrm{C}$ for further analysis.

Coccygeal venous plasma samples were prepared for AA determination; individual AA and ammonia were then separated by ion-exchange chromatography (Beckman model 6300 amino acid analyzer, Beckman Instruments Inc., Palo Alto, CA).

Coccygeal venous plasma samples were analyzed for $\mathrm{Na}^{+}, \mathrm{K}^{+}, \mathrm{Cl}^{-}, \mathrm{Ca}$, urea $\mathrm{N}$, and creatinine using the same analytical methods as for the urine. Also, plasma glucose, BHBA, and NEFA were measured spectrophotometrically. All of these assays were performed on the Hitachi 917 analyzer (Roche) using Roche diagnostic reagents.

Milk Production and $\boldsymbol{B W}$. Milk production was measured at 0600 and $1500 \mathrm{~h}$ daily. Milk samples were collected weekly from 6 to 47 DIM. Samples from consecutive p.m. and a.m. milkings were composited based on production and then analyzed for milk fat, true protein, lactose, SNF, SCC, and urea $\mathrm{N}$ by an infrared method using a Milkoscan System 4000 (Foss North American, Eden Prairie, MN; Dairy Lab Services, Dubuque, IA). Milk samples were collected from a.m. milking, refrigerated at $4^{\circ} \mathrm{C}$, and measured for $\mathrm{pH}$ within $2 \mathrm{~h}$. The BW was determined weekly from 6 to 47 DIM.

\section{Statistical Analysis}

Data on daily DMI and milk yield were reduced to weekly means for each cow. Jugular venous blood, urine and milk $\mathrm{pH}$ were converted to free $\mathrm{H}^{+}$concentration $\left(\left[\mathrm{H}^{+}\right]\right.$, assuming an activity coefficient of 1$)$ and subjected to statistical analysis (Murphy, 1982). The resulting mean $\left[\mathrm{H}^{+}\right]$could still be transformed for convenience and reported as $\mathrm{pH}$. Therefore, each mean was presented as both $\left[\mathrm{H}^{+}\right]$and $\mathrm{pH}$; because of the asymmetric standard error of $\mathrm{pH}$ resulted from transformation, the larger number was presented as the standard error of $\mathrm{pH}$ (Murphy, 1982).

Weekly data were analyzed using the MIXED procedure (SAS Institute, 2001) with a repeated-measures model. Cow was treated as a random variable, and breed (i.e., Holstein and Jersey) was included as an extra between-cow effect. The first-order autoregressive structure type was selected as the appropriate covariance structure based on the goodness-of-fit criteria (Littell et al., 1998). The model was

$$
\begin{aligned}
\mathrm{Y}_{\mathrm{ijk}}= & \mu+\mathrm{B}_{\mathrm{i}}+\mathrm{W}_{\mathrm{j}}+\mathrm{T}_{\mathrm{k}}+(\mathrm{B} \times \mathrm{W})_{\mathrm{ij}}+(\mathrm{B} \times \mathrm{T})_{\mathrm{ik}} \\
& +(\mathrm{W} \times \mathrm{T})_{\mathrm{jk}}+(\mathrm{B} \times \mathrm{W} \times \mathrm{T})_{\mathrm{ijk}}+\mathrm{e}_{\mathrm{ijk}}
\end{aligned}
$$

where $\mu=$ overall mean; $B_{i}=$ effect of breed $i$ ( $i=1$, $2) ; \mathrm{W}_{\mathrm{j}}=$ effect of week $\mathrm{j}(\mathrm{j}=1,2,3,4,5,6) ; \mathrm{T}_{\mathrm{k}}=$ effect of treatment $\mathrm{k}(\mathrm{k}=1,2) ;(\mathrm{B} \times \mathrm{W})_{\mathrm{ij}}=$ effect of interaction between breed i with week j; $(\mathrm{B} \times \mathrm{T})_{\mathrm{ik}}=$ effect of interaction between breed $\mathrm{i}$ with treatment $\mathrm{k} ;(\mathrm{W} \times \mathrm{T})_{\mathrm{jk}}=$ effect of interaction between week $j$ with treatment $k$; $(\mathrm{B} \times \mathrm{W} \times \mathrm{T})_{\mathrm{ijk}}=$ effect of interaction among breed $\mathrm{i}$, week $\mathrm{j}$, and treatment $\mathrm{k}$; and $\mathrm{e}_{\mathrm{ijk}}=$ error term.

Significance was defined as $P \leq 0.05$; whereas 0.05 $<P \leq 0.10$ was considered to indicate a trend toward a significant effect.

\section{RESULTS AND DISCUSSION}

\section{Diets}

Ingredient and chemical composition of experimental diets are shown in Table 1. Corn silage was fed to dairy cows as the sole forage fiber source, and dietary $\mathrm{ADF}$ and NDF average contents of the 2 experimental diets were 15.0 and $26.7 \%$, respectively. An analysis of TMR particle size by dry sieving (Murphy and Zhu, 1997) found that $13.4 \%$ was $>6.3 \mathrm{~mm}, 20.8 \%>4.75$ $\mathrm{mm}, 30.6 \%>3.35 \mathrm{~mm}, 38.5 \%>2.36 \mathrm{~mm}, 50.3 \%>1.7$ $\mathrm{mm}$, and $68.0 \%>1.18 \mathrm{~mm}$; therefore, average particle size was $1.8 \mathrm{~mm}$ and the $\log _{10}$ standard deviation was 0.49 .

Dietary CP concentrations were $<1 \%$ higher than formulated (19\%). A higher than expected Na content of the grain mix resulted in a higher DCAD of 51.1 than the formulated $47 \mathrm{mEq} / 100 \mathrm{~g}$ of DM. To balance the $\mathrm{P}$ contents or other nutrients in both experimental diets, dicalcium phosphate was added, resulting in 
Table 2. Least squares means of DMI, milk yield, $4 \%$ FCM, and milk composition in 2 breeds fed diets with 2 levels of DCAD

\begin{tabular}{|c|c|c|c|c|c|c|c|}
\hline \multirow[b]{2}{*}{ Variable } & \multicolumn{2}{|c|}{$\mathrm{DCAD}^{1}$} & \multicolumn{2}{|c|}{ Breed } & \multirow[b]{2}{*}{$\mathrm{SE}$} & \multicolumn{2}{|c|}{ Effect $(P)$} \\
\hline & 22 & 47 & Holstein & Jersey & & DCAD & Breed \\
\hline DMI, kg/d & 18.2 & 18.3 & 19.9 & 16.7 & 2.2 & $\mathrm{NS}^{2}$ & $<0.01$ \\
\hline $\mathrm{DMI}, \mathrm{kg} / \mathrm{kg}$ of $\mathrm{BW}^{0.75}$ & 0.163 & 0.164 & 0.349 & 0.372 & 0.019 & NS & NS \\
\hline $\mathrm{BW}, \mathrm{kg}$ & 554 & 540 & 636 & 458 & 27 & NS & $<0.01$ \\
\hline \multicolumn{8}{|l|}{ Milk } \\
\hline Yield, kg/d & 33.5 & 33.3 & 38.2 & 28.6 & 3.0 & NS & $<0.01$ \\
\hline $4 \% \mathrm{FCM}, \mathrm{kg} / \mathrm{d}$ & 32.8 & 33.3 & 35.6 & 30.5 & 3.9 & NS & 0.01 \\
\hline Fat, \% & 3.96 & 4.11 & 3.58 & 4.49 & 0.65 & NS & $<0.01$ \\
\hline Fat, $\mathrm{kg} / \mathrm{d}$ & 1.29 & 1.33 & 1.35 & 1.27 & 0.23 & NS & NS \\
\hline Protein, $\%$ & 3.11 & 3.00 & 2.74 & 3.38 & 0.23 & NS & $<0.01$ \\
\hline Protein, kg/d & 1.03 & 0.98 & 1.04 & 0.96 & 0.14 & NS & NS \\
\hline Lactose, \% & 4.88 & 4.92 & 4.93 & 4.87 & 0.12 & NS & NS \\
\hline Lactose, $\mathrm{kg} / \mathrm{d}$ & 1.64 & 1.64 & 1.88 & 1.40 & 0.21 & NS & $<0.01$ \\
\hline $\mathrm{SNF}, \%$ & 8.95 & 8.83 & 8.57 & 9.22 & 0.27 & NS & $<0.01$ \\
\hline $\mathrm{SNF}, \mathrm{kg} / \mathrm{d}$ & 2.99 & 2.91 & 3.26 & 2.64 & 0.34 & NS & $<0.01$ \\
\hline Urea, mg of N/dL & 21.8 & 23.6 & 21.8 & 23.5 & 4.3 & NS & NS \\
\hline $\mathrm{SCC}, \times 1,000 / \mathrm{mL}$ & 152 & 254 & 236 & 171 & 366 & NS & NS \\
\hline
\end{tabular}

${ }^{1} \mathrm{DCAD}$ in milliequivalents of $(\mathrm{Na}+\mathrm{K}-\mathrm{Cl}-\mathrm{S}) / 100 \mathrm{~g}$ of DM.

${ }^{2} \mathrm{NS}=P>0.10$.

higher dietary $\mathrm{P}$ contents (average of $0.58 \%$ ) than required for dairy cows (NRC, 2001).

\section{$D M I$ and $B W$}

Table 2 presents DMI and DMI per unit of metabolic body size for cows fed DCAD of 22 or $47 \mathrm{mEq} / 100 \mathrm{~g}$ of DM postpartum. As expected, both DMI $(P<0.01)$ and DMI per unit of metabolic body size $(P<0.01)$ increased with week of lactation. However, DMI expressed as kilograms per day or kilograms per unit of metabolic body size were not affected by treatment. No treatment effect on BW was observed.

\section{Milk Yield and Composition}

Milk yield and 4\% FCM were similar for postpartum cows fed diets with DCAD of 22 or $47 \mathrm{mEq} / 100 \mathrm{~g}$ of DM (Table 2). Likewise, milk fat, true protein, lactose, and SNF percentages and yields; urea $\mathrm{N}$; and SCC were similar between treatments. These results suggested that increasing DCAD from 22 to $47 \mathrm{mEq} / 100$ $\mathrm{g}$ of DM did not affect performance. West et al. (1992) reported similar results; milk yield and milk fat and protein percentage did not differ in heat-stressed cows fed diets with varying DCAD of 12 to $46 \mathrm{mEq}(\mathrm{Na}+$ $\mathrm{K}-\mathrm{Cl}) / 100 \mathrm{~g}$ of DM. Tucker et al. (1988) found that cows yielded $9 \%$ more milk when fed DCAD of +20 vs. $-10 \mathrm{mEq}(\mathrm{Na}+\mathrm{K}-\mathrm{Cl}) / 100 \mathrm{~g}$ of DM, but milk fat concentration and fat yield were unaffected. Milk fat concentration and fat yield, in contrast, increased with increasing DCAD of 23 to $88 \mathrm{mEq} / 100 \mathrm{~g}$ of $\mathrm{DM}$ in pasture-based dairy cows in early lactation (Roche et al., 2005). It was shown that different ranges of DCAD were used in those different experiments; the range of DCAD could impact experimental results.

\section{Milk pH and Jugular Venous Blood Acid-Base Status}

A change of DCAD from 22 to $47 \mathrm{mEq} / 100 \mathrm{~g}$ of DM did not affect milk $\mathrm{pH}$, jugular venous blood $\mathrm{pH}$, $\mathrm{HCO}_{3}{ }^{-}, \mathrm{pCO}_{2}, \mathrm{pO}_{2}$, or base excess (Table 3 ). However, increasing DCAD would be expected to improve acidbase status in lactating cows, indicated by increased blood $\mathrm{pH}$ and $\mathrm{HCO}_{3}{ }^{-}$(Hu and Murphy, 2004). Anion gap represents the difference between the concentration of unmeasured anions and the concentration of unmeasured cations in serum and can be expressed as a concentration of $\mathrm{K}^{+}+\mathrm{Na}^{+}-\mathrm{Cl}^{-}-\mathrm{HCO}_{3}{ }^{-}$(Constable, 1999, 2000). Its usefulness in evaluating acid-base status in lactating dairy cows is unclear. However, jugular venous blood anion gap tended to have a higher concentration for the diet with DCAD of $47 \mathrm{vs} .22 \mathrm{mEq} /$ $100 \mathrm{~g}$ of DM $(P=0.06)$; anion gap differed $(P=0.04)$ between the Holstein and Jersey cows (Table 3). It implied that the diet might be less acidogenic with a DCAD of 47 vs. $22 \mathrm{mEq} / 100 \mathrm{~g}$ of DM, and that less blood acidity might exist in Jersey vs. Holstein cows postpartum. Minerals $(\mathrm{Na}, \mathrm{K}, \mathrm{Cl}$, and $\mathrm{Ca}$ ) in both whole blood collected from the jugular vein and blood plasma collected from the coccygeal vein were determined in the present experiment. There was no treatment effect on mineral concentrations of the 2 blood samples except for jugular venous blood $\mathrm{Cl}^{-}$; jugular venous blood $\mathrm{Cl}^{-}$concentration tended to decrease $(P=$ 
Table 3. Least squares means of milk $\mathrm{pH}$, jugular venous blood acid-base measures and mineral concentrations in 2 breeds fed diets with 2 levels of DCAD

\begin{tabular}{|c|c|c|c|c|c|c|c|}
\hline \multirow[b]{2}{*}{ Variable } & \multicolumn{2}{|c|}{$\mathrm{DCAD}^{1}$} & \multicolumn{2}{|c|}{ Breed } & \multirow[b]{2}{*}{$\mathrm{SE}$} & \multicolumn{2}{|c|}{ Effect $(P)$} \\
\hline & 22 & 47 & Holstein & Jersey & & DCAD & Breed \\
\hline \multicolumn{8}{|l|}{ Milk } \\
\hline $\begin{array}{l}\mathrm{H}^{+} \text {concentration, } \mathrm{n} M \\
\mathrm{pH}\end{array}$ & $\begin{array}{l}230 \\
6.64\end{array}$ & $\begin{array}{l}225 \\
6.65\end{array}$ & $\begin{array}{r}217 \\
6.66\end{array}$ & $\begin{array}{l}238 \\
6.62\end{array}$ & $\begin{array}{c}43.3 \\
0.09\end{array}$ & $\mathrm{NS}^{2}$ & NS \\
\hline \multicolumn{8}{|l|}{ Blood } \\
\hline $\begin{array}{l}\mathrm{H}^{+} \text {concentration, } \mathrm{n} M \\
\mathrm{pH}\end{array}$ & $\begin{array}{l}40.3 \\
7.395\end{array}$ & $\begin{array}{l}39.8 \\
7.400\end{array}$ & $\begin{array}{l}39.7 \\
7.401\end{array}$ & $\begin{array}{l}40.4 \\
7.394\end{array}$ & $\begin{array}{l}1.94 \\
0.022\end{array}$ & NS & NS \\
\hline $\mathrm{pCO}_{2}, \mathrm{mmHg}$ & 46.7 & 46.5 & 46.9 & 46.4 & $\begin{array}{l}0.02 \\
3.9\end{array}$ & NS & NS \\
\hline $\mathrm{pO}_{2}, \mathrm{mmHg}$ & 25.9 & 26.1 & 25.5 & 26.5 & 2.7 & NS & NS \\
\hline $\mathrm{HCO}_{3}^{-}, \mathrm{mEq} / \mathrm{L}$ & 27.3 & 27.6 & 27.8 & 27.2 & 2.8 & NS & NS \\
\hline Base excess, $\mathrm{m} M$ & 2.53 & 2.97 & 3.16 & 2.34 & 2.58 & NS & NS \\
\hline $\mathrm{Na}^{+}, \mathrm{mEq} / \mathrm{L}$ & 132.9 & 132.5 & 132.7 & 132.6 & 1.7 & NS & NS \\
\hline $\mathrm{K}^{+}, \mathrm{mEq} / \mathrm{L}$ & 3.99 & 3.93 & 4.01 & 3.91 & 0.27 & NS & NS \\
\hline $\mathrm{Cl}^{-}, \mathrm{mEq} / \mathrm{L}$ & 98.8 & 97.6 & 98.7 & 97.7 & 2.0 & 0.06 & NS \\
\hline $\mathrm{Ca}^{2+}, \mathrm{mg} / \mathrm{dL}$ & 4.62 & 4.68 & 4.73 & 4.57 & 0.39 & NS & 0.09 \\
\hline $\mathrm{BCAD},{ }^{3} \mathrm{mEq} / \mathrm{L}$ & 38.1 & 38.9 & 38.1 & 39.0 & 2.2 & NS & NS \\
\hline Anion gap, ${ }^{4} \mathrm{mEq} / \mathrm{L}$ & 10.4 & 11.4 & 10.3 & 11.4 & 2.0 & 0.06 & 0.04 \\
\hline
\end{tabular}

${ }^{1} \mathrm{DCAD}$ in milliequivalents of $(\mathrm{Na}+\mathrm{K}-\mathrm{Cl}-\mathrm{S}) / 100 \mathrm{~g}$ of $\mathrm{DM}$.

${ }^{2} \mathrm{NS}=P>0.10$.

${ }^{3} \mathrm{BCAD}=$ jugular venous blood cation-anion difference $(\mathrm{Na}+\mathrm{K}-\mathrm{Cl})$.

${ }^{4}$ Anion gap $=$ jugular venous blood $\mathrm{Na}^{+}+\mathrm{K}^{+}-\mathrm{Cl}^{-}-\mathrm{HCO}_{3}^{-}$.

0.06) as DCAD increased from 22 to $47 \mathrm{mEq} / 100 \mathrm{~g}$ of DM. In addition, a tendency of jugular venous blood $\mathrm{Ca}^{2+}$ to be lower $(P=0.09)$ was observed in Jersey vs. Holstein cows.

The lack of responses in milk performance and blood acid-base status to DCAD might be attributed to the stage of lactation. The transition from the pregnant, nonlactating state to the nonpregnant, lactating state imposes enormous stress on dairy cows, greatly increasing susceptibility to metabolic disorders (Goff and Horst, 1997). The tremendous physiological challenges to the homeostatic mechanisms of the cows during this stage contribute to the large variation in milk yield, DMI, or other responses to dietary treatments (Drackley, 1999). A calculation was performed to estimate how large a difference of treatment effects would likely be detectable in a similar future experiment (Ott and Longnecker, 2001). Given 12 dairy cows in each treatment group and standard errors of milk yield $(3.0 \mathrm{~kg} / \mathrm{d})$ and DMI $(2.2 \mathrm{~kg} / \mathrm{d}$; Table 2$)$, if a $95 \%$ confidence level and $80 \%$ statistical power were specified, the detectable differences of milk yield and DMI between the 2 treatments were 3.4 and $2.5 \mathrm{~kg} / \mathrm{d}$, respectively.

\section{Coccygeal Venous Plasma Metabolites}

Effects of experiment diets on coccygeal venous plasma metabolites are presented in Table 4. There were no effects of treatments or interactions involving treatment on coccygeal venous plasma concentrations of urea N, ammonia, creatinine, glucose, BHBA, and NEFA, except for an interaction between treatment and breed for creatinine $(P=0.03)$. Creatinine concentrations of Holstein and Jersey cows were 0.72 and $0.55 \mathrm{mg} / \mathrm{dL}$ for DCAD of $22 \mathrm{mEq} / 100 \mathrm{~g}$ of $\mathrm{DM}$, and 0.69 and $0.65 \mathrm{mg} / \mathrm{dL}$ for DCAD of $47 \mathrm{mEq} / 100 \mathrm{~g}$ of DM, respectively. Interestingly, higher NEFA $(P=0.01)$, and lower glucose $(P=0.01)$ and creatinine $(P<0.01)$ in coccygeal venous plasma were also observed in Jersey vs. Holstein cows.

\section{Coccygeal Venous Plasma AA}

Higher concentrations of His $(P=0.02)$, Ile $(P=$ $0.01)$, Leu $(P<0.01)$, Lys $(P=0.02)$, Phe $(P=0.02)$, Val $(P=0.01)$, and total branched-chain AA (BCAA; $P<0.01$ ) were observed for cows with DCAD of $47 \mathrm{vs}$. $22 \mathrm{mEq} / 100 \mathrm{~g}$ of DM (Table 5). For the nonessential AA (NEAA), only Glu was affected by the experimental diets $(P<0.01)$. There was no effect of interactions involving treatments on coccygeal venous plasma AA, except for an interaction of treatment by breed on Glu $(P<0.01)$. Coccygeal venous plasma Glu concentrations of Holstein and Jersey cows were 58.9 and 52.8 $\mu M$ for DCAD of $22 \mathrm{mEq} / 100 \mathrm{~g}$ of DM, and 59.4 and $66.8 \mu M$ for DCAD of $47 \mathrm{mEq} / 100 \mathrm{~g}$ of $\mathrm{DM}$, respectively. Because of higher essential AA (EAA; $P<0.01)$ in cows with DCAD of $47 \mathrm{vs} .22 \mathrm{mEq} / 100 \mathrm{~g}$ of DM, greater ratios of EAA to NEAA $(P=0.01)$ and of EAA to total AA (TAA; $P=0.01$ ) were observed in cows with DCAD of $47 \mathrm{vs} .22 \mathrm{mEq} / 100 \mathrm{~g}$ of DM. 
Table 4. Least squares means of coccygeal venous plasma metabolites and mineral concentrations in 2 breeds fed diets with 2 levels of DCAD

\begin{tabular}{|c|c|c|c|c|c|c|c|}
\hline \multirow[b]{2}{*}{ Variable } & \multicolumn{2}{|c|}{$\mathrm{DCAD}^{1}$} & \multicolumn{2}{|c|}{ Breed } & \multirow[b]{2}{*}{$\mathrm{SE}$} & \multicolumn{2}{|c|}{ Effect $(P)$} \\
\hline & 22 & 47 & Holstein & Jersey & & DCAD & Breed \\
\hline Urea $\mathrm{N}, \mathrm{mg} / \mathrm{dL}$ & 22.2 & 22.5 & 21.1 & 23.6 & 3.2 & $\mathrm{NS}^{2}$ & 0.09 \\
\hline Ammonia, $\mathrm{m} M$ & 0.545 & 0.549 & 0.548 & 0.545 & 0.073 & NS & NS \\
\hline Creatinine, $\mathrm{mg} / \mathrm{dL}$ & 0.64 & 0.67 & 0.71 & 0.60 & 0.08 & NS & $<0.01$ \\
\hline Glucose, mg/dL & 56.5 & 54.4 & 57.6 & 53.2 & 5.3 & NS & 0.01 \\
\hline BHBA, $\mathrm{mM}$ & 0.64 & 0.66 & 0.67 & 0.63 & 0.43 & NS & NS \\
\hline $\mathrm{NEFA}, \mathrm{mEq} / \mathrm{L}$ & 0.55 & 0.56 & 0.39 & 0.73 & 0.33 & NS & 0.01 \\
\hline $\mathrm{Na}^{+}, \mathrm{mEq} / \mathrm{L}$ & 138.8 & 138.2 & 138.6 & 138.4 & 2.8 & NS & NS \\
\hline $\mathrm{K}^{+}, \mathrm{mEq} / \mathrm{L}$ & 4.14 & 4.18 & 4.23 & 4.09 & 0.26 & NS & NS \\
\hline $\mathrm{Cl}^{-}, \mathrm{mEq} / \mathrm{L}$ & 98.5 & 97.4 & 98.5 & 97.4 & 2.3 & NS & NS \\
\hline $\mathrm{Ca}, \mathrm{mg} / \mathrm{dL}$ & 9.49 & 9.59 & 9.46 & 9.62 & 0.65 & NS & NS \\
\hline $\mathrm{PCAD},{ }^{3} \mathrm{mEq} / \mathrm{L}$ & 44.2 & 44.8 & 44.1 & 44.9 & 2.4 & NS & NS \\
\hline
\end{tabular}

${ }^{1} \mathrm{DCAD}$ in milliequivalents of $(\mathrm{Na}+\mathrm{K}-\mathrm{Cl}-\mathrm{S}) / 100 \mathrm{~g}$ of DM.

${ }^{2} \mathrm{NS}=P>0.10$.

${ }^{3} \mathrm{PCAD}=$ coccygeal venous plasma cation-anion difference $(\mathrm{Na}+\mathrm{K}-\mathrm{Cl})$.

Protein flowing to the small intestine depends on the amount of dietary protein escaping ruminal degradation, microbial protein synthesis, and the abomasal emptying rate. The BCAA, relative to other AA, are less degraded by the liver and serve as indicators of AA supply to the small intestine in dairy cows (Lobley,

Table 5. Least squares mean concentrations of AA in coccygeal venous plasma ( $\mu \mathrm{mol} / \mathrm{L})$ in 2 breeds fed diets with 2 levels of DCAD

\begin{tabular}{|c|c|c|c|c|c|c|c|}
\hline \multirow[b]{2}{*}{ Variable } & \multicolumn{2}{|c|}{$\mathrm{DCAD}^{1}$} & \multicolumn{2}{|c|}{ Breed } & \multirow[b]{2}{*}{$\mathrm{SE}$} & \multicolumn{2}{|c|}{ Effect $(P)$} \\
\hline & 22 & 47 & Holstein & Jersey & & DCAD & Breed \\
\hline \multicolumn{8}{|l|}{ Essential AA (EAA) } \\
\hline Arg & 76 & 82 & 83 & 75 & 16 & $\mathrm{NS}^{2}$ & 0.05 \\
\hline His & 44.3 & 47.9 & 42.1 & 50.0 & 6.3 & 0.02 & $<0.01$ \\
\hline Ile & 99 & 127 & 115 & 110 & 31 & 0.01 & NS \\
\hline Leu & 118 & 156 & 137 & 138 & 33 & $<0.01$ & NS \\
\hline Lys & 84 & 97 & 87 & 93 & 18 & 0.02 & NS \\
\hline Met & 16.9 & 17.5 & 18.0 & 16.3 & 4.3 & NS & NS \\
\hline Phe & 42 & 48 & 46 & 44 & 8 & 0.02 & NS \\
\hline Thr & 87 & 95 & 96 & 87 & 17 & NS & NS \\
\hline Trp & 48 & 50 & 45 & 52 & 20 & NS & NS \\
\hline Val & 214 & 276 & 240 & 250 & 65 & 0.01 & NS \\
\hline \multicolumn{8}{|l|}{ Nonessential AA (NEAA) } \\
\hline Ala & 201 & 214 & 207 & 207 & 32 & NS & NS \\
\hline Asp & 18.5 & 21.2 & 18.8 & 20.9 & 3.2 & NS & NS \\
\hline Asn & 101 & 106 & 117 & 91 & 36 & NS & NS \\
\hline Glu & 56 & 63 & 59 & 60 & 7 & $<0.01$ & NS \\
\hline Gln & 269 & 243 & 296 & 216 & 70 & NS & 0.01 \\
\hline Gly & 432 & 415 & 409 & 438 & 86 & NS & NS \\
\hline Pro & 75 & 83 & 77 & 81 & 14 & NS & NS \\
\hline Ser & 113 & 109 & 113 & 109 & 24 & NS & NS \\
\hline Tyr & 38 & 41 & 42 & 36 & 10 & NS & 0.06 \\
\hline \multicolumn{8}{|l|}{ Other AA } \\
\hline Citrulline & 101 & 105 & 103 & 102 & 21 & NS & NS \\
\hline Hydroxyproline & 25 & 24 & 27 & 21 & 10 & NS & 0.02 \\
\hline Ornithine & 47 & 50 & 50 & 48 & 10 & NS & NS \\
\hline Branched-chain AA & 431 & 558 & 492 & 497 & 122 & $<0.01$ & NS \\
\hline EAA & 829 & 995 & 908 & 916 & 164 & $<0.01$ & NS \\
\hline NEAA & 1,303 & 1,292 & 1,339 & 1,257 & 175 & NS & NS \\
\hline Total AA (EAA + NEAA) & 2,131 & 2,286 & 2,245 & 2,172 & 287 & 0.06 & NS \\
\hline Urea cycle AA & 225 & 236 & 236 & 225 & 35 & NS & NS \\
\hline EAA:NEAA & 0.650 & 0.776 & 0.687 & 0.738 & 0.122 & 0.01 & NS \\
\hline EAA:total AA & 0.390 & 0.434 & 0.402 & 0.421 & 0.041 & 0.01 & NS \\
\hline
\end{tabular}

${ }^{1} \mathrm{DCAD}$ in milliequivalents of $(\mathrm{Na}+\mathrm{K}-\mathrm{Cl}-\mathrm{S}) / 100 \mathrm{~g}$ of DM.

${ }^{2} \mathrm{NS}=P>0.10$. 
Table 6. Least squares means of urine $\mathrm{pH}$ and urine component concentrations in 2 breeds fed diets with 2 levels of DCAD

\begin{tabular}{|c|c|c|c|c|c|c|c|}
\hline \multirow[b]{2}{*}{ Variable } & \multicolumn{2}{|c|}{$\mathrm{DCAD}^{1}$} & \multicolumn{2}{|c|}{ Breed } & \multirow[b]{2}{*}{$\mathrm{SE}$} & \multicolumn{2}{|c|}{ Effect $(P)$} \\
\hline & 22 & 47 & Holstein & Jersey & & DCAD & Breed \\
\hline $\mathrm{H}^{+}$concentration, $\mathrm{n} M$ & 7.66 & 6.25 & 6.88 & 7.03 & 2.30 & 0.08 & $\mathrm{NS}^{2}$ \\
\hline $\mathrm{pH}$ & 8.12 & 8.20 & 8.16 & 8.15 & 0.18 & & \\
\hline Creatinine, $\mathrm{mg} / \mathrm{dL}$ & 58 & 44 & 57 & 45 & 17 & 0.01 & 0.02 \\
\hline $\mathrm{TA},{ }^{3} \mathrm{~m} M$ & -116 & -158 & -135 & -138 & 41 & 0.02 & NS \\
\hline Ammonium, $\mathrm{m} M$ & 9.5 & 8.7 & 8.2 & 10.0 & 4.4 & NS & NS \\
\hline $\mathrm{NAE}^{,}{ }^{4} \mathrm{~m} M$ & -107 & -149 & -127 & -128 & 41 & 0.01 & NS \\
\hline TA:creatinine, $\mathrm{m} M: \mathrm{m} M$ & -26 & -43 & -31 & -38 & 13 & $<0.01$ & 0.06 \\
\hline Ammonium:creatinine, $\mathrm{m} M: \mathrm{m} M$ & 1.99 & 2.17 & 1.68 & 2.48 & 0.92 & NS & $<0.01$ \\
\hline NAE:creatinine, $\mathrm{m} M: \mathrm{m} M$ & -24 & -41 & -29 & -35 & 13 & $<0.01$ & 0.1 \\
\hline Urea N:creatinine, mg:mg & 16.4 & 17.3 & 14.5 & 19.2 & 2.7 & NS & $<0.01$ \\
\hline $\mathrm{Na}^{+}$:creatinine, mg:mg & 2.43 & 3.76 & 2.85 & 3.34 & 1.76 & $<0.01$ & NS \\
\hline $\mathrm{K}^{+}$:creatinine, mg:mg & 10.22 & 14.18 & 10.39 & 14.00 & 3.06 & $<0.01$ & 0.01 \\
\hline $\mathrm{Cl}^{-}$:creatinine, mg:mg & 1.56 & 1.78 & 1.28 & 2.09 & 0.94 & NS & $<0.01$ \\
\hline Ca:creatinine, mg:mg & 0.39 & 0.43 & 0.26 & 0.56 & 0.29 & NS & $<0.01$ \\
\hline
\end{tabular}

\footnotetext{
${ }^{1} \mathrm{DCAD}$ in milliequivalents of $(\mathrm{Na}+\mathrm{K}-\mathrm{Cl}-\mathrm{S}) / 100 \mathrm{~g}$ of $\mathrm{DM}$.

1992; Dhiman and Satter, 1997). In the present experiment, DMI was not affected by diet treatment; coccygeal venous plasma concentrations of Ile, Leu, and Val, and of BCAA (Ile + Leu + Val), plasma ratios of EAA to NEAA and of EAA to TAA were higher in the diet with a DCAD of $47 \mathrm{vs} .22 \mathrm{mEq} / 100 \mathrm{~g}$ of DM. Therefore, more protein apparently reached the small intestine for absorption with DCAD of 47 vs. $22 \mathrm{mEq} / 100 \mathrm{~g}$ of DM. Because microbial protein synthesized in the rumen supplies the majority of AA flowing to the small intestine of dairy cows (Bach et al., 2005), elevated coccygeal venous plasma BCAA and EAA concentrations with DCAD of $47 \mathrm{vs} .22 \mathrm{mEq} / 100 \mathrm{~g}$ of DM probably resulted from increased microbial protein synthesis.

Addition of buffers such as $\mathrm{NaHCO}_{3}$ increases DCAD. The DCAD may have similar effects on ruminal $\mathrm{N}$ metabolism as buffers. Buffers are expected to increase protein solubility in the rumen by raising ruminal $\mathrm{pH}$ and, consequently, to increase protein degradability (Trenkle, 1979). Okeke et al. (1983) reported an increased rate of $\mathrm{N}$ disappearance of soybean meal from nylon bags in the rumen of steers supplemented with 2.5 or $5 \% \mathrm{NaHCO}_{3}$. However, increased ruminal $\mathrm{pH}$ and dilution rate by buffer addition results in higher microbial growth rates, which could offset increased protein degradability. Mees et al. (1985) observed increased bacterial $\mathrm{N}$ flow at the duodenum and efficiency of bacteria protein synthesis in sheep with addition of $\mathrm{NaHCO}_{3}$ to the diet. Further research is warranted to elucidate the role of DCAD in manipulating ruminal $\mathrm{N}$ metabolism and potentially increasing protein flow to the small intestine.

\section{Urine $\mathrm{pH}, \mathrm{TA}$, and Minerals}

Because excretion of creatinine is relatively constant (De Groot and Aafjes, 1960; Albin and Clanton, 1966; Asai et al., 2005), urine creatinine concentration was used as an index to estimate excretion of metabolites and minerals in urine. Urine creatinine was affected by DCAD $(P=0.01)$; higher creatinine concentration in cows with DCAD of $22 \mathrm{mEq} / 100 \mathrm{~g}$ of DM (Table 6) suggested that more concentrated urine was excreted and, consequently, total daily urine volumes were less than those for cows with DCAD of $47 \mathrm{mEq} /$ $100 \mathrm{~g}$ of DM.

Urine $\mathrm{pH}$ tended to be higher $(P=0.08$, based on $\left.\left[\mathrm{H}^{+}\right]\right)$for cows with DCAD of $47 \mathrm{vs} .22 \mathrm{mEq} / 100 \mathrm{~g}$ of DM (Table 6). Urine $\mathrm{pH}$ is very sensitive to the supplementation of acidogenic salts in prepartum cows (Vagnoni and Oetzel, 1998; Charbonneau et al., 2006), but changing DCAD from 22 to $47 \mathrm{mEq} / 100 \mathrm{~g}$ of DM had a relatively small effect on urine $\mathrm{pH}$. The normal $\mathrm{pH}$ of bovine urine, like that of all herbivores, is greater than 8 (Oetzel, 2002). Therefore, cows fed with DCAD of $22 \mathrm{mEq} / 100 \mathrm{~g}$ of $\mathrm{DM}$ or higher maintained a normal urine $\mathrm{pH}$ (i.e., >8.0).

Most excreted urine $\mathrm{H}^{+}$are associated with buffers or ammonia, in addition to free $\mathrm{H}^{+}$excreted in the urine. Decreased TA:creatinine $(P<0.01)$ and unchanged ammonium:creatinine was noted for cows 
with DCAD of 47 vs. $22 \mathrm{mEq} / 100 \mathrm{~g}$ of DM. Consequently, NAE:creatinine decreased $(P<0.01)$ in cows with DCAD of $47 \mathrm{vs} .22 \mathrm{mEq} / 100 \mathrm{~g}$ of DM. The NAE result indicated that acid-base status differed for cows with DCAD of 22 vs. $47 \mathrm{mEq} / 100 \mathrm{~g}$ of $\mathrm{DM}$ and confirmed that urinary NAE could be a much more sensitive indicator of metabolic acid load in dairy cows than blood acid-base parameters (Erdman, 1988).

The DCAD was manipulated by $\mathrm{NaHCO}_{3}$ and $\mathrm{K}_{2} \mathrm{CO}_{3}$ addition. Addition of $\mathrm{NaHCO}_{3}$ and $\mathrm{K}_{2} \mathrm{CO}_{3}$ would increase urinary $\mathrm{Na}$ and $\mathrm{K}$ excretion. In the present experiment (Table 6), higher $\mathrm{Na}^{+}$excretion, as $\mathrm{Na}^{+}$:creatinine $(P<0.01)$ and higher $\mathrm{K}^{+}$excretion, as $\mathrm{K}^{+}$:creatinine $(P<0.01)$ were observed in cows with DCAD of 47 vs. $22 \mathrm{mEq} / 100 \mathrm{~g}$ of $\mathrm{DM}$, reflecting diet contents (Table 1). Urinary mineral excretions were much more responsive than plasma mineral concentrations to dietary mineral contents. In addition, urinary Ca excretion, as Ca:creatinine, did not differ with DCAD of 22 vs. $47 \mathrm{mEq} / 100 \mathrm{~g}$ of DM, but differed ( $P$ $<0.01$ ) between the Holstein and Jersey cows (Table 6). Jersey cows are more susceptible to parturient paresis, likely because of their high milk production in relation to their body size. Nonetheless, tending to have lower coccygeal blood plasma $\mathrm{Ca}^{2+}$, together with higher Ca excretion in Jersey vs. Holstein cows postpartum as discussed above, might have implications in susceptibility of parturient paresis.

\section{CONCLUSIONS}

The DMI and performance of dairy cows immediately postpartum were not improved when DCAD increased from 22 to $47 \mathrm{mEq} / 100 \mathrm{~g}$ of DM. Cows at this stage of lactation respond more variably to dietary treatments, making treatment effects difficult to detect. Jugular venous blood $\mathrm{pH}$ and $\mathrm{HCO}_{3}{ }^{-}$remained similar, whereas blood $\mathrm{Cl}^{-}$concentration tended to decrease as DCAD increased from 22 to $47 \mathrm{mEq} / 100 \mathrm{~g}$ of DM. Higher NAE with DCAD of 22 vs. $47 \mathrm{mEq} /$ $100 \mathrm{~g}$ of DM suggested that NAE was a much more sensitive indicator of acid load than blood acid-base parameters in cows postpartum. Elevated coccygeal venous plasma BCAA and ratio of EAA to TAA in cows with DCAD of $47 \mathrm{vs} .22 \mathrm{mEq} / 100 \mathrm{~g}$ of $\mathrm{DM}$ indicated that $\mathrm{N}$ metabolism in the rumen was affected, probably resulting in more microbial protein flowing to the small intestine.

\section{REFERENCES}

Albin, R. C., and D. C. Clanton. 1966. Factors contributing to the variation in urinary creatinine and creatinine-nitrogen ratios in beef cattle. J. Anim. Sci. 25:107-112.

Asai, H., N. Hayashi, N. Takai, Y. Yoshimura, Y. Nakamura, H. Yokota, and K. Kita. 2005. Estimation of daily urinary pot- assium excretion using urinary creatinine as an index substance in prepartum dairy cows. Anim. Sci. J. 76:51-54.

Bach, A., S. Calsamiglia, and M. D. Stern. 2005. Nitrogen metabolism in the rumen. J. Dairy Sci. 88(E Suppl.):E9-E21.

Chan, J. C. M. 1972. The rapid determination of urinary titratable acid and ammonium and evaluation of freezing as a method of preservation. Clin. Biochem. 5:94-98.

Chan, P. S., J. W. West, J. K. Bernard, and J. M. Fernandez. 2005. Effects of dietary cation-anion difference on intake, milk yield, and blood components of the early lactation cow. J. Dairy Sci. 88:4384-4392.

Charbonneau, E., D. Pellerin, and G. R. Oetzel. 2006. Impact of lowering dietary cation-anion difference in nonlactating dairy cows: A meta-analysis. J. Dairy Sci. 89:537-548.

Constable, P. D. 1999. Clinical assessment of acid-base status. Strong ion difference theory. Vet. Clin. North Am. Food Anim. Pract. 15:447-471.

Constable, P. D. 2000. Clinical assessment of acid-base status: Comparison of the Henderson-Hasselbalch and strong ion approaches. Vet. Clin. Pathol. 29:115-128.

De Groot, Th., and J. H. Aafjes. 1960. On the constancy of creatinine excretion in the urine of the dairy cow. Br. Vet. J. 116:409-418.

Delaquis, A. M., and E. Block. 1995a. The effects of changing ration ingredients on acid-base status, renal function, and macromineral metabolism. J. Dairy Sci. 78:2024-2039.

Delaquis, A. M., and E. Block. 1995b. Dietary cation-anion difference, acid-base status, mineral metabolism, renal function, and milk production of lactating cows. J. Dairy Sci. 78:2259-2284.

Dhiman, T. R., and L. D. Satter. 1997. Effect of ruminally degraded protein on protein available at the intestine assessed using amino acid concentrations. J. Anim. Sci. 75:1674-1680.

Drackley, J. K. 1999. Biology of dairy cows during the transition period: The final frontier? J. Dairy Sci. 82:2259-2273.

Erdman, R. A. 1988. Dietary buffering requirements of the lactating dairy cow: A review. J. Dairy Sci. 71:3246-3266.

Goff, J. P., and R. L. Horst. 1997. Physiological changes at parturition and their relationship to metabolic disorders. J. Dairy Sci. 80:1260-1268.

Hu, W., and M. R. Murphy. 2004. Dietary cation-anion difference effects on performance and acid-base status of lactating dairy cows: A meta-analysis. J. Dairy Sci. 87:2222-2229.

Littell, R. C., P. R. Henry, and C. B. Ammerman. 1998. Statistical analysis of repeated measures data using SAS procedures. J. Anim. Sci. 76:1216-1231.

Lobley, G. E. 1992. Control of metabolic fate of amino acids in ruminants: A review. J. Anim. Sci. 70:3264-3275.

Mees, D. C., N. R. Merchen, and C. J. Mitchel. 1985. Effects of sodium bicarbonate on nitrogen balance, bacterial protein synthesis and sites of nutrient digestion in sheep. J. Anim. Sci. 61:985-994.

Murphy, M. R. 1982. Analyzing and presenting $\mathrm{pH}$ data. J. Dairy Sci. 65:161-163.

Murphy, M. R., and J. S. Zhu. 1997. A comparison of methods to analyze particle size as applied to alfalfa haylage, corn silage, and concentrate mix. J. Dairy Sci. 80:2932-2938.

NRC. 2001. Nutrient Requirements of Dairy Cattle. 7th rev. ed. Natl. Acad. Sci., Washington, DC.

Oetzel, G. R. 2002. The dietary cation-anion difference concept in dairy cattle nutrition: Possibility and pitfalls. Pages 198-208 in Recent Developments and Perspectives in Bovine Medicine: XXII World Buiatrics Congress. M. Kaske, H. Scholz, and M. Holtershinken, ed. Hannover, Germany.

Okeke, G. C., J. G. Buchanan-Smith, and W. L. Grovum. 1983. Effects of buffers on ruminal rate of passage and degradation of soybean meal in steers. J. Anim. Sci. 56:1393-1399.

Ott, R. L., and M. Longnecker. 2001. An introduction to statistical methods and data analysis. 5th ed. Duxbury, Thomson Learning Inc., Pacific Grove, CA.

Roche, J. R., S. Petch, and J. K. Kay. 2005. Manipulating the dietary cation-anion difference via drenching to early-lactation dairy cows grazing pasture. J. Dairy Sci. 88:264-276.

SAS Institute. 2001. SAS system software: Release 8.2 (TS2M0). SAS Institute Inc., Cary, NC. 
Shah, M. A., E. J. Friedman, A. O. Bahaa, and M. R. Murphy. 2004. Effect of liquid flavor supplementation of the diet on dairy cows in the transition period. J. Dairy Sci. 87:1872-1877.

Trenkle, A. 1979. The relationship between acid-base balance and protein metabolism in ruminants. Pages 146-157 in Regulation of Acid-Base Balance. W. H. Hale and P. Meinhardt, ed. Church and Dwight Co. Inc., Piscataway, NJ.

Tucker, W. B., G. A. Harrison, and R. W. Hemken. 1988. Influence of dietary cation-anion balance on milk, blood, urine, and rumen fluid in lactating dairy cattle. J. Dairy Sci. 71:346-354.
Vagnoni, D. B., and G. R. Oetzel. 1998. Effects of dietary cationanion difference on the acid-base status of dry cows. J. Dairy Sci. 81:1643-1652.

West, J. W., K. D. Haydon, B. G. Mullinix, and T. G. Sandifer. 1992. Dietary cation-anion balance and cation source effects on production and acid-base status of heat-stressed cows. J. Dairy Sci. 75:2776-2786.

West, J. W., B. G. Mullinix, and T. G. Sandifer. 1991. Changing dietary electrolyte balance for dairy cows in cool and hot environments. J. Dairy Sci. 74:1662-1674. 